"Gulielmus Solerij civis Maioricarum me fecit anno a Nat. Domini Mccclxxxv."

As considerable difficulty is often found in fixing the position of places in the interior of Australia, the following note of the distance in miles from Adelaide of each station on the overland telegraph line which terminates at Port Darwin on the northern coast, will be found useful :Beltana, 355; Strangway Springs, 565; Peake, 636 ; Charlotte Waters, 804; Alice Springs, I,036; Barrow's Creek, I,207; Tennant's Creek, I,354; Powell's Creek, I,467; Daly Waters, I,605 ; River Katherine, I,77 I ; Pine Creek, I, 825 ; Yam Creek, I, 854 ; Southport, I,934 ; Port Darwin, I,973. Considerable progress is being made with the trigonometrical survey of South Australia. We also learn that an exploring expedition from Queensland has just completed a flying survey across the northern portion of both colonies, large tracts of which are still practically unknown.

EXCELLENT news from Abbé Debaise has arrived in Marseilles.

THE Inter-Oceanic Congress has adopted, by 98 votes against 8 , the proposal in favour of cutting the canal through the Isthmus of Panama, by the Bay of Limon, to Panama.

DR. MicLUCHO MACLAY, the Russian explorer, with an Italian, Chevalier Bruno, and Capt. Leeman, have sailed from Sydney for New Guinea, in the American schooner Laddie, F. Caller, chartered for a twelvemonth's cruise. $2,500 l$. has been spent or the equipment. The expedition is intended to be both scientific and commercial. New Caledonia, New Britain, and other islands are to be visited.

THE first part of Dr. Nachtigal's new work: "Reisen in Afrika," comprising his journey across the desert to Bornu, is about to be published by Messrs. Wiegandt, Hempel, and Parey, Berlin.

A TElegram from Gordon Pasha to the Italian Geographical Society, announces that Capt. Martini, the leader of the Italian expedition which is going to assist the Marchese Antinori, has obtained permission to enter Abyssinia, that he had left CEdowa, and had landed at Massanah.

\section{THE FIRST OBSERVATIONS OF SUN-SPOTS}

$\Delta \mathrm{T}$ p. 284 of NATURE, vol. i., the following paragraph A occurs :-

"Dr. Kirkwood commences by reminding us that the most ancient observations of sun-spots of which we have any record, are those of the Chinese in the year 32 I A D.; the first notice of their detection by Europeans being found in the Annals of the Frankish Kings. A black spot, according to Adelmus, was seen on the sun's disk March I5, 807, and continued visible eight days. Simiiar phenomena were again observed from May 28 to August 26, A.D. 840 . The year 1096 was also signalised by the appearance of spots so large as to be visible to the naked eye. The next date, in chronological order, is that of I161, when a spot was seen by Averröes. Finally, on December 7, 8, and 16, I590, 'a great blacke spot on the sunne' was observed at sea by those on board the ship Richard of Arundell. The foregoing are, we believe, the only undoubted instances in which these phenomena were observed previous to the invention of the telescope.'"

During the winter of $1877-78$ the late Mr. Mayers, Chinese Secretary of the British Legation in Peking, purchased on behalf of the British Museum a large Chinese Encyclopæedia, comprising 5,020 volumes, and containing the most valuable information, historical, literary, and scientific. Unfortunately, however, its records end with the Ming dynasty, A.D. 1628. Whilst preparations were being made for its shipment to London, a sub-section of this immense work, entitled "Natural Phenomena," was placed at my disposal for purposes of research. I resolved to confine my attention to obtaining records (I) of the droughts and famines that had visited China, and (2) of the sun-spots observed by the Chinese.

The records of the droughts and famines are most minute. The years, months, and districts affected are given in detail.

With regard to sun-spots ${ }^{1}$ [black spots on the sun ${ }^{2}$ ] I found that from B.C. 28 to A.D. 1617 fifty-six observations were recorded, and that ten other observations of what I have translated sun-shadows, ${ }^{3}$ four of them prior to the first sun-spot observation, were mentioned. These observations are exhibited in the annexed table, from which it will be seen that undoubted sun-spots were visible in China on three occasions previous to the year A.D. $321-$ the date given by Pere Mailla in his "Annales de la Chine"-namely, in the years A.D. 301, 302, and 307. The solar phenomena observed in 807 and 840 are also mentioned in the Chinese record.

The remarks regarding the apparent sides of the sunspots, \&c., are literal translations of the Chinese text.

\begin{tabular}{|c|c|c|c|c|c|c|}
\hline \multirow{2}{*}{\multicolumn{2}{|c|}{ Year. }} & \multicolumn{2}{|r|}{ Moon. } & \multicolumn{3}{|r|}{ Remarks. } \\
\hline & & $\ldots$ & & & & \\
\hline & 20 & $\cdots$ & 23 & $\ldots$ & Black & hadows. \\
\hline A.D. & 188 & $\cdots$ & $1\}$ & $\cdots$ & Hrack & (... \\
\hline & 300 & $\cdots$ & 1) & & & \\
\hline & 301 & $\cdots$ & 9 & & & \\
\hline & 302 & $\cdots$ & $11-12$ & & & \\
\hline & 307 & $\ldots$ & II & & & \\
\hline & $3^{21}$ & $\ldots$ & 2 & & & \\
\hline & 322 & $\ldots$ & 10 & & & \\
\hline & 342 & $\ldots$ & I & & & \\
\hline & 344 & $\cdots$ & IO & & & \\
\hline & 345 & $\ldots$ & 3 & & & \\
\hline & 359 & $\ldots$ & ro & $\ldots$ & Size o & an egg. \\
\hline & 360 & $\ldots$ & 4 & & & \\
\hline & $3^{61}$ & $\ldots$ & 2 & & & \\
\hline & $37^{2}$ & $\ldots$ & II & $\ldots$ & Size o & a plum. \\
\hline & 373 & $\ldots$ & 3,11 & $\ldots$ & Size o & an egg. \\
\hline & 388 & $\ldots$ & 2 & $\ldots$ & Two s & ots ; size of plums. \\
\hline & 389 & $\ldots$ & 6 & & & \\
\hline & 395 & $\cdots$ & I I & & & \\
\hline & 400 & $\ldots$ & II & & & \\
\hline & 499 & $\cdots$ & $\begin{array}{l}2 \\
8\end{array}$ & $\ldots$ & Three & pots ; size of peaches. \\
\hline & $\begin{array}{l}501 \\
502\end{array}$ & $\cdots$ & $\begin{array}{r}8 \\
1-2\end{array}$ & $\ldots$ & Two s & ots visible. \\
\hline & 509 & $\ldots$ & 8 & $\ldots$ & Black & hadows. \\
\hline & 510 & $\ldots$ & 2 & $\ldots$ & ," & , \\
\hline & 513 & $\ldots$ & $I-4$ & $\ldots$ & ", & ," \\
\hline & 577 & $\cdots$ & II & & & \\
\hline & 580 & $\ldots$ & 2 & & & \\
\hline & 807 & $\cdots$ & IO & & & \\
\hline & 826 & $\cdots$ & 3 & & & \\
\hline & 832 & $\ldots$ & $3-4$ & & & \\
\hline & 837 & $\ldots$ & II & $\cdots$ & Size o & an egg. \\
\hline & 840 & $\ldots$ & 2 & $\ldots$ & Black & hadows. \\
\hline & 841 & $\ldots$ & II & & & \\
\hline & 865 & $\ldots$ & I & $\ldots$ & Black & hadows. \\
\hline & 874 & $\ldots$ & - & & & \\
\hline & 974 & $\cdots$ & I & & & \\
\hline & 1077 & $\cdots$ & 2 & $\ldots$ & Size 0 & a plum. \\
\hline & $107^{8}$ & $\ldots$ & 1,12 & $\ldots$ & ", & , \\
\hline & 1079 & $\ldots$ & 2 & $\ldots$ & ", & 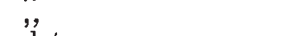 \\
\hline & I 104 & $\ldots$ & 10 & $\ldots$ & ", & date. \\
\hline & 1105 & $\ldots$ & IO & & & \\
\hline & III 2 & $\cdots$ & 4 & & & \\
\hline & III 8 & $\ldots$ & II & $\ldots$ & Size 0 & a plum. \\
\hline & I 120 & $\ldots$ & 5 & & & \\
\hline & 1129 & $\cdots$ & 3 & & & \\
\hline & II 3 I & $\ldots$ & 2 & $\ldots$ & $\begin{array}{l}\text { Size o } \\
\text { Size o }\end{array}$ & $\begin{array}{l}\text { a plum; } \\
\text { a plum. }\end{array}$ \\
\hline & II $3^{6}$ & $\ldots$ & IO-II & & slze o & \\
\hline & I I 37 & $\ldots$ & $2-4$ & $\ldots$ & ", & " \\
\hline
\end{tabular}
"See the Fournal of the North China Branch of the Royal Asiatic Society for I878: "Droughts in China, A.D. 620-1643,", and "Sun-Spots and SunShadows Observed in China, B.C. $28-A$.D. 1677.

2 This is a literal translation of the Chinese text, may also be translated 3 The Chincse character
"breath," "vapuur," \&ce. 


\begin{tabular}{|c|c|c|c|c|c|}
\hline $\begin{array}{l}\text { Year. } \\
\text { II } 38\end{array}$ & & Moon. & & Remarks. & \\
\hline 1139 & $\ldots$ & 2,10 & & & \\
\hline II 45 & $\ldots$ & 6 & $\ldots$ & Black shadows and spots. & \\
\hline 1160 & $\ldots$ & 8 & & & \\
\hline 1185 & $\ldots$ & I & ... & Size of an egg. & \\
\hline I 186 & $\cdots$ & 5 & $\cdots$ & ,, & \\
\hline 193 & $\cdots$ & $\int_{12}$ & & & \\
\hline $\begin{array}{l}1200 \\
1202\end{array}$ & .. & $8, \mathbf{I} 2$ & & & \\
\hline $\begin{array}{l}1202 \\
1204\end{array}$ & $\cdots$ & 12 & $\cdots$ & Size of an egg. & \\
\hline 1205 & $\ldots$ & 4 & & & \\
\hline 1238 & $\ldots$ & IO & & & \\
\hline 1276 & ... & - & $\cdots$ & Size of a goose's egg. & \\
\hline $\mathbf{I} 370$ & $\cdots$ & - & $\cdots$ & $\begin{array}{l}\text { Spots were frequently } \\
\text { during this year. }\end{array}$ & observed \\
\hline 2511 & ... & 5 & ... & Black shadows. & \\
\hline 1529 & $\cdots$ & 2 & ... &,$\quad$, & \\
\hline 1617 & ... & - & & ALEXANDER & HosIE \\
\hline
\end{tabular}

NATIONAL WATER-SUPPLY EXHIBITION

H YDE PARK and Trafalgar Square experiences have very plainly shown that the simplest way to induce a clamorous populace to forget what they fancy they want, is to let them hold their meetings and pass resolutions. It is a matter of such very small exertion to hold up a hand in favour of a resolution compared with taking any personal trouble to see that any steps are taken towards carrying it into effect. Human nature is only in certain phases influenced by a man's occupation, and whether resolutions are passed by "labourers" or by "professional gentlemen," they stand much the same chance of being forgotten after the press has recorded that they have been passed. Last year the Society of Arts in loyal response to the request of its Royal President, held a conference to discuss the watersupply question. After two days' work a resolution was carried urging that a small scientific commission should be appointed to collect information and suggest further inquiries on the subject. Twelve months elapsed and a few days ago another conference was held, when it was made known that the only step taken with regard to that resolution was that just before the Conference it had reached the Lords of the Treasury. Last year the Society directed that a résumé and sort of index should be made of what had been done by Parliamentary inquiries and official reports with regard to water-supplies, and the result was a volume called "Notes on Previous Inquiries," which, though very incomplete, may serve as a basis for a larger and more comprehensive work. The very fact of the imperfections in these notes showed to those more immediately connected with their compilation the need of enlisting wider sympathies if anything of real value was to be printed. A letter in the Times of April I4 of this year mentioned that although the notes had been published for many months, "not a single word" had been sent in response to the request printed on the back of the titlepage that suggestions or corrections should be sent to the secretary. The idea was then suggested of founding a permanent free museum for the purpose of keeping before the public mind those subjects, apart from the question of low rates only, which should be considered in arranging water-supplies. It was decided that a temporary exhibition should be first tried as an experiment and after some difficulties in finding it a locale, the management of the Royal Aquarium kindly arranged for the use of the south gallery for the purpose. This exhibition is now open and a handbook is issued. It is marked "under revision," and on the title-page attention is appropriately drawn to the fact that it is the first public exhibition of the kind.

This handbook, we are told, has been drawn up under great disadvantages in many ways. One great difficulty has been that the exhibition has grown beyond what seemed at first likely to be its extent, and entries for the handbook have come from time to time, though but slowly. This was, perhaps, to be expected in an exhibition, the first of its kind, which was, therefore, to some extent, an experiment; and that many should hold aloof till success was assured was but natural. Although this gradual growth is a matter that must be a satisfaction to those interested in spreading a knowledge of what a study of water-supply means, it has entailed much unexpected labour on the part of the management.

Among those who have helped in the scientific sections are-Col. Beaumont, M.P., Col. Bolton, Baldwin Latham, F.R.S., J. G. Symons, F.R.S., J. E. Gardner, F.S.A., Dr. Granville Cole, Prof. Wanklyn, Prof. G. Bischoff, W. Cooper, Joseph Lucas, F.G.S., A. T. Atchison, M.A., C. E. De Rance, H.M.G.S., F.G.S., J. B. Jordan, F.G.S.

The comprehensive scope of the exhibition may be gathered from the following list of the sections into which it is divided :-

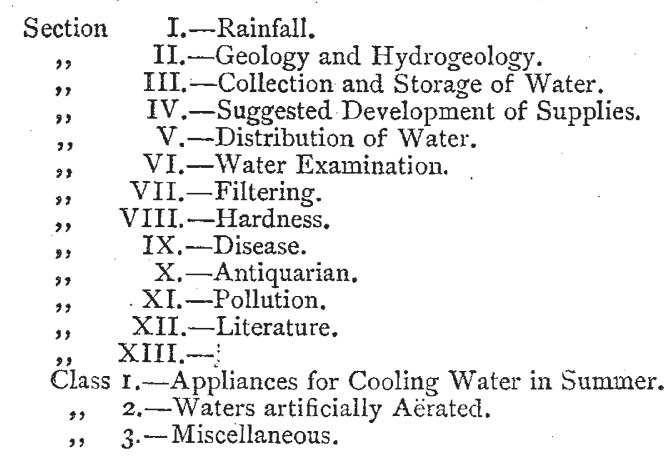

A scientific committee has been formed to draw up a report on the exhibition, especially to point out what defects should be remedied in future exhibitions of the kind, and it is announced that next week "demonstrations" will be given on the sections embracing scientific apparatus.

\section{NATURAL SCIENCE DEGREES AT OXFORD}

MANY of our readers have no doubt noticed the scheme which some soi-disant "friends of science" in authority at Oxford have brought forward professedly in the interests of science. One of the prime movers in the new scheme for the creation of B.N.S. and M.N.S. degrees is Canon Liddon, who insists that for the degree of Arts Greek shall be indispensable, but for the inferior degrees in science may be dispensed with. Since the meeting of congregation at which the scheme was discussed, there has been much correspondence in the Times on the subject, the letters of most importance being those of Canon Liddon and Prof. Odling. The former in his correspondence professes to have the interests of natural science purely at heart in the creation of the new degree, which, he maintains, would give facilities to a much wider class to obtain the stamp of the University than if Greek were insisted on, as he maintains must be the case with the degree of the university. The opposition of Prof. Odling and those who think with him, is not to the creation of a degree in natural science, but to any course that would degrade it in public estimation. He urges on the university the desirability of framing such statutes in reference to any such degree, as shall assure it a high place in general estimation, and shall more especially obtain for it the approval and sympathy of the cultivators of natural science. He considers it important to this end that the possession of a degree in natural science shall imply on the part of the student, first, general cultivation, and second, special knowledge in some branch of science. But according to the proposed innovation, if 